\title{
PENGGUNAAN RASIO KEUANGAN DALAM MEMPREDIKSI PERTUMBUHAN LABA PADA DISTRIBUTOR PRIMA PALOPO
}

\author{
Amran ${ }^{* 1}$, Rosmayanti. A $^{2}$ \\ 1Universitas Muhammadiyah Makassar \\ ${ }^{2}$ Sekolah Tinggi Ilmu Ekonomi Muhammadiyah Palopo \\ *amranpare@gmail.com
}

\begin{abstract}
This study aims to determine the financial ratios which consist of the debt to equity ratio, the working capital to total assets ratio, the total assets turn over ratio and the net profit margin ratio that have no significant effect in predicting profit growth at Prima Palopo Distributors. The research sample is taken from the Prima Palopo Distributor financial report for six years, from 2009 to 2014. From the data analysis that has been done above, it can be concluded that together financial ratios consisting of debt to equity ratio, working capital to total assets ratio, total assets turn over ratio and net profit margin ratio did not have a significant effect in predicting profit growth at Prima Palopo Distributors. The results are proven by the F test where the significance of 0.190 is greater than 0.05. For the results of the partial analysis the $t$ test is described as follows: obtained a positive debt to equity ratio and net profit margin ratio of 0.021 and 2.023, respectively. This shows that the debt to equity ratio and net profit margin ratio have a positive effect on profit growth at Prima Palopo Distributors. While the significance value of 0.862 and 0.222 is greater than 0.05 , which means that the debt to equity ratio and net profit margin ratio do not have a significant effect in predicting profit growth in Prima Palopo Distribution. While the working capital to total assets ratio and total assets turn over ratio have negative and insignificant effect, this is needed by the t test obtained by the regression coefficient for the working capital to total assets ratio and the total assets turn over ratio of -1.586 and -0.497 and significance for the calculation of 0.380 and 0.450 .
\end{abstract}

Keywords: Debt To Equity Ratio, Working Capital To Total Assets Ratio,Total Assets Turn Over Ratio, Net Profit Margin Ratio

\begin{abstract}
Abstrak
Penelitian ini bertujuan untuk mengetahui rasio keuangan yang terdiri dari debt to equity ratio, working capital to total assets ratio, total assets turn over ratio dan net profit margin ratio tidak berpengaruh signifikan dalam memprediksi pertumbuhan laba pada Distributor Prima Palopo. Sampel penelitian diambil yaitu laporan keuangan Distributor Prima Palopo selama enam tahun yaitu dari tahun 2009 sampai 2014. Dari analisis data yang telah dilakukan di atas, maka dapat disimpulkan bahwa secara bersama-sama rasio keuangan yang terdiri dari debt to equity ratio, working capital to total assets ratio, total assets turn over ratio dan net profit margin ratio tidak berpengaruh signifikan dalam memprediksi pertumbuhan laba pada Distributor Prima Palopo. Hasil tersebut dibuktikan dengan uji F dimana diperoleh signifikansi sebesar 0,190 lebih besar dari 0,05.Untuk hasil analisis secara parsial dengan uji t dijabarkan sebagai berikut: diperoleh debt to equity ratio dan net profit margin ratio bernilai positif yaitu masing-masing 0,021 dan 2,023, hal ini menunjukkan bahwa debt to equity ratio dan net profit margin ratio berpengaruh positif terhadap pertumbuhan laba pada Distributor Prima Palopo. Sedangkan nilai signifikansi sebesar 0,862 dan 0,222 lebih besar dari 0,05 yang berarti bahwa debt to equity ratio dan net profit margin ratio tidak berpengaruh signifikan dalam memprediksi pertumbuhan laba pada Distibutor Prima Palopo. Sedangkan untuk working capital to total assets ratio dan total assets turn over ratio berpengaruh negatif dan tidak signifikan, hali ini dibutikan dengan uji t diperoleh koefisien regresi untuk working capital to total assets ratio dan total assets turn over ratio sebesar $-1,586$ dan -0,479 dan signifikansi sebesar 0,380 dan 0,450.
\end{abstract}

Kata Kunci: Debt To Equity Ratio, Working Capital To Total Assets Ratio,Total Assets Turn Over Ratio, Net Profit Margin Ratio 


\section{PENDAHULUAN}

Setiap perusahaan dalam aktivitasnya selalu membutuhkan dana untuk memenuhi permodalannya. Dalam memperoleh dana, perusahaan dapat melakukan berbagai upaya diantaranya laba ditahan, utang dan penerbitan saham (Bambang Riyanto, 2001:1). Diantara berbagai macam alternatif sumber dana tersebut, laba menjadi salah satu indikator yang sangat potensial karena dengan mengetahui laba perusahaan, secara sekilas dapat diketahui perkembangan keuangan suatu perusahaan. Apabila perkembangannya bagus, tentunya investor dan kreditur tidak ragu-ragu dalam berinvestasi dan memberikan kredit kepada perusahaan.

Beberapa penelitian tentang rasio keuangan telah banyak dilakukan di Indonesia. Diantaranya, Penelitian Zainudin dan Jogiyanto Hartono adalah penggunaan rasio keuangan dalam memprediksi pertumbuhan laba. Hasil dari penelitian tersebut menunjukkan bahwa perubahan rasio keuangan pada construct rasio keuangan capital, assets, earnings, dan liquidity signifikan dalam memprediksi pertumbuhan laba perusahaan perbankan untuk tahun satu tahun ke depan, tetapi tidak untuk dua tahun ke depan. Adapun tiga rasio keuangan tahun 2000 dapat digunakan untuk memprediksi perubahan laba tahun 2001 dan rasio keuangan pada tahun 2001 tidak dapat memprediksi perubahan laba tahun 2002.

Penelitian ini merupakan replikasi dari penelitian Agus Endro Suwarno. Variabel independen penelitian ini menggunakan empat rasio keuangan untuk mengetahui pengaruhnya terhadap perubahan laba yaitu Rasio leverage (Debt Equity Ratio), Rasio Likuiditas (Current Rasio), Rasio Aktivitas (Total Asset Turn Over), dan Rasio Profitabilitas (Return on Assets). Pemilihan beberapa rasio dalam penelitian ini karena melihat beberapa hasil penelitian tentang pengaruh rasio keuangan terhadap laba sangat bervariatif, sehingga peneliti ingin menganalisis kembali penelitian sebelumnya dari sudut fundamental perusahaan yaitu rasio-rasio yang berhubungan dengan laba untuk mewakili keseluruhan kelompok rasio.

Penelitian-penelitian terdahulu masih banyak dilakukan pada perusahaanperusahaan yang tergabung dalam bursa konvensional. Hal tersebut membuat penyusun tertarik untuk melakukan penelitian yang serupa dengan mengambil variabel yang berbeda untuk menjelaskan apakah penelitian yang dilakukan akan menghasilkan kesimpulan yang sama atau tidak dengan penelitian terdahulu yang telah dilakukan.

Berdasarkan penjelasan-penjelasan di atas, maka penyusun tertarik untukmelakukan penelitian dengan judul "Penggunaan Rasio Keuangan dalam Memprediksi Pertumbuhan Laba Pada Distributor Prima Palopo".

\section{TINJAUAN PUSTAKA DAN PERUMUSAN HIPOTESIS}

\section{Pertumbuhan Laba \\ Pengertian dan Karakteristik Laba}

Laba secara operasional merupakan perbedaan antara pendapatan yang direalisasi yang timbul dari transaksi selama satu periode dengan biaya yang berkaitan dengan pendapatan tersebut. Sedangkan pengertian laba menurut Ikatan Akuntan Indonesia (IAI) dalam Chariri dan Ghozali (2003:213), adalah kenaikan manfaat ekonomi selama satu periode akuntansi dalam bentuk pemasukan atau penambahan aktiva atau penurunan kewajiban yang mengakibatkan kenaikan ekuitas yang tidak berasal dari kontribusi peranan modal. Sementara pengertian laba yang dianut oleh struktur akuntansi sekarang ini adalah laba akuntansi yang merupakan selisih pengukuran pendapatan dan biaya. Besar kecilnya laba sebagai pengukur kenaikan sangat bergantung pada ketepatan pengukuran pendapatan dan biaya.

\section{Faktor-Faktor yang Mempengaruhi Pertumbuhan Laba Analisis Pertumbuhan Laba}


Menurut Anoraga dan Pakarti dalam Angkoso (2006:102), ada dua macam analisis untuk menentukan pertumbuhan laba yaitu analisis fundamental dan analisis teknikal.

Analisis Fundamental

Analisis fundamental merupakan analisis yang berhubungan dengan kondisi keuangan perusahaan. Dengan analisis fundamental diharapkan calon investor akan mengetahui bagaimana operasional dari perusahaan yang nantinya menjadi milik investor, apakah sehat atau tidak, apakah menguntungkan atau tidak dan sebagainya. Hal ini penting karena nantinya akan berhubungan dengan hasil yang akan diperoleh dari investasi dan resiko yang harus ditanggung.

Analisis fundamental merupakan analisis historis atas kekuatan keuangan dari suatu perusahaan yang sering disebut dengan company analysis. Data yang digunakan adalah data historis, artinya data yang telah terjadi dan mencerminkan keadaan keuangan yang sebenarnya pada saat analisis. Dalam company analysis para analis akan menganalisis laporan keuangan perusahaan yang salah satunya dengan rasio keuangan.

Analisis Teknikal

Analisis teknikal sering dipakai oleh investor, dan biasanya data atau catatan pasar yang digunakan berupa grafik. Analisis ini berupaya untuk memprediksi pertumbuhan laba di masa yang akan datang dengan mengamati perubahan laba di masa lalu. Teknik ini mengabaikan hal-hal yang berkaitan dengan posisi keuangan perusahaan.

\section{Rasio Keuangan}

\section{Pengertian Rasio Keuangan}

Menurut Munawir (2002:64), pengertian rasio adalah rasio menggambarkan suatu hubungan atau perimbangan (mathematical Relation Ship). Antara suatu jumlah tertentu dengan jumlah yang lain dan dengan menggunakan alat analisa yang berupa rasio ini akan dapat menjelaskan atau memberi gambaran kepada penganalisa tentang baik atau buruknya keadaan atau posisi keuangan terutama apabila angka rasio tersebut dibandingkan dengan angka rasio pembanding yang digunakan sebagai standar". Debt to Assets Ratio

Rasio ini menekankan pentingnya pendanaan hutang dengan jalan menunjukkan persentase aktiva perusahaan yang didukung oleh hutang. Rasio ini juga menyediakan informasi tentang kemampuan perusahaan dalam mengadaptasi kondisi pengurangan aktiva akibat kerugian tanpa mengurangi pembayaran bunga pada kreditor.

Debt to Assets Ratio dapat dihitung dengan rumus:

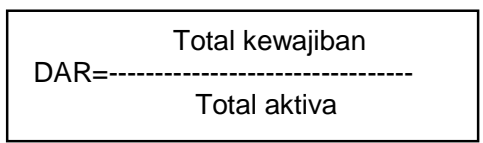

Debt to Equity Ratio

Rasio ini menunjukkan persentase penyediaan dana oleh pemegang saham terhadap pemberi pinjaman.

Debt to Equity Ratio dapat dihitung dengan rumus:

\begin{tabular}{c} 
Total kewajiban \\
DER = Total ekuitas \\
\hline
\end{tabular}

\section{Equity Multiplier}

Rasio ini menunjukkan kemampuan perusahaan dalam mendayagunakan ekuitas pemegang saham.Rasio ini juga bisa diartikan sebagai berapa porsi dari aktiva perusahaan yang dibiayai oleh pemegang saham.

Equity Multiplier apat dihitung dengan rumus:

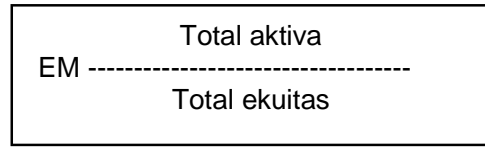

Interest Coverage (IC) atau Times Interest Karned

Rasio ini berguna untuk mengetahui kemampuan laba dalam membayar biaya bunga untuk periode sekarang.

Interest Coverage dapat dihitung dengan menggunakan rumus:

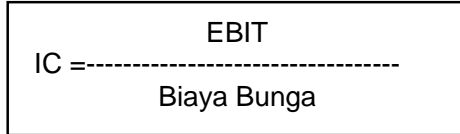

\section{Rasio Likuiditas}


Rasio Likuiditas adalah rasio-rasio yang dimaksudkan untuk mengukur likuiditas perusahaan. Rasio likuiditas bertujuan untuk mengetahui kemampuan perusahaan dalam membayar kewajiban jangka pendek, meliputi: Current Ratio

Current Ratio adalah kemampuan perusahaan dalam memenuhi kewajiban jangka pendek dengan aktiva lancar yang dimiliki.

Current Ratio dapat dihitung dengan rumus:

$\mathrm{CR}=\quad$ - Kewajiban Lancar

Quick Test Ratio

Quick test ratio adalah kemampuan aktiva lancar minus persediaan untuk membayar kewajiban lancar.

Quick test ratio dapat dihitung dengan rumus:

\begin{tabular}{|c|c|}
\hline \multirow{2}{*}{ QTR = } & $\begin{array}{c}\text { Kas+Investasi jangka } \\
\text { pendek+piutang dagang bersih }\end{array}$ \\
\hline & Kewajiban Lancar \\
\hline
\end{tabular}

Net Working Capital atau Modal Kerja Bersih

Rasio modal kerja bersih digunakan untuk mengetahui rasio modal bersih terhadap kewajiban lancar.

Rasio modal kerja ini dapat dihitung dengan rumus:

\begin{tabular}{|cc|}
\hline $\mathrm{NWC}=$ & Aktiva Lancar-kewajiban lancar \\
& Kewajiban Lancar \\
\hline
\end{tabular}

Working Capital to Total Asset

Working Capital to Total Asset merupakan salah satu rasio likuiditas yang menunjukkan kemampuan perusahaan dalam menggunakan aktiva lancar perusahaan, sehingga mampu membayar utang jangka pendeknya tepat pada waktu yang dibutuhkan.

Working Capital to Total Asset dapat dihitung dengan rumus:

\begin{tabular}{|cc|}
\hline WCTA $=$ & Aktiva Lancar-kewajiban lancar \\
---------------------- \\
Jumlah Aktiva
\end{tabular}

\section{Rasio Aktivitas}

Rasio-rasio Aktivitas yaitu rasio-rasio yang dimaksudkan untuk mengukur sampai seberapa besar efektivitas perusahaan dalam mengerjakan sumber-sumber dayanya. Rasio aktivitas bertujuan untuk menggambarkan aktivitas yang dilakukan perusahaan dalam menjalankan operasinya. Rasio ini meliputi:

\section{Receivable Turn Over}

Rasio ini menggambarkan kualitas piutang perusahaan dan kesuksesan perusahaan dalam penagihan piutang yang dimiliki.

Receivable Turn Over dapat dihitung dengan rumus:

$$
\text { RTO = } \frac{\text { Penjualan bersih }}{\text { Rata-rata piutang dagang }}
$$

Rata-rata Penerimaan Piutang

Dengan melihat rasio ini, kita bisa melihat dalam jangka waktu berapa hari piutang akan bisa diubah menjadi kas atau ditagih.

Rata-rata penerimaan piutang dapat dihitung dengan rumus:

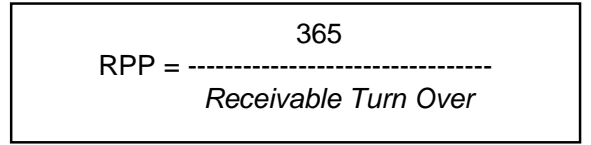

Inventory Turn Over

Rasio ini berguna untuk mengetahui kemampuan perusahaan dalam mengelola persediaan, dalam arti berapa kali persediaan yang ada akan diubah menjadi penjualan.

Inventory Turn Over dapat dihitung dengan rumus:

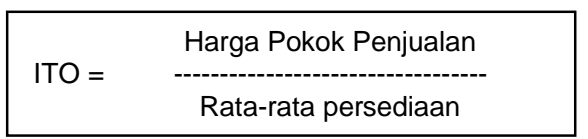

Lama Persediaan Mengendap

Rasio ini berguna untuk mengetahui jangka waktu persediaan mengendap di gudang perusahaan.

Lama persediaan mengendap dapat dihitung dengan rumus:

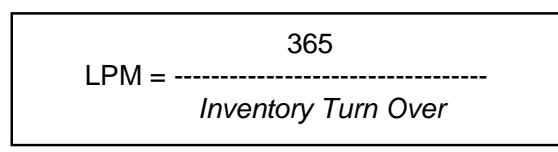

Kemampuan perusahaan dalam menggunakan aktiva yang dimiliki untuk menghasilkan penjualan digambarkan dalam rasio ini. Dengan melihat rasio ini, kita bisa 
mengetahui efektivitas penggunaan aktiva dalam menghasilkan penjualan.

Total Assts Turn Over dapat dihitung dengan rumus:

\begin{tabular}{|l}
\hline TATO $=\quad$ Penjualan bersih \\
\hline- Rata-rata total aktiva
\end{tabular}

\section{a. Rasio Profitabilitas}

Rasio-rasio Profitabilitas yaitu rasio-rasio yang menunjukan hasil akhir dari sejumlah kebijaksanaan dan keputusan-keputusan. Rasio profitabilitas bertujuan untuk mengetahui kemampuan perusahaan dalam menghasilkan laba. Rasio ini meliputi:

1) Gross Profit Margin

Rasio ini berguna mengetahui keuntungan kotor perusahaan dari setiap barang yang dijual.

Gross Profit Margin dapat dihitung dengan rumus:

\begin{tabular}{|c|c|}
\hline \multirow{2}{*}{ GPM = } & Penjualan bersih-HP \\
\hline & Penjualan bersih \\
\hline
\end{tabular}

Rasio ini menggambarkan besarnya laba bersih yang diperoleh oleh perusahaan pada setiap penjualan yang dilakukan. Rasio ini tidak menggambarkan besarnya persentase keuntungan bersih yang diperoleh perusahaan untuk setiap penjualan karena adanya unsur pendapatan dan biaya non operasional.

Net Profit Margin dapat dihitung dengan rumus:

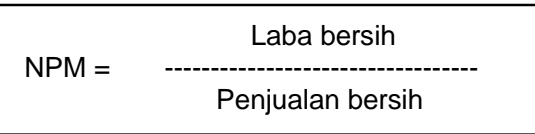

4) Return on Assets

Rasio ini menggambarkan kemampuan perusahaan untuk menghasilkan keuntungan dari setiap satu rupiah aset yang digunakan. Dengan mengatahui rasio ini, kita bisa menilai apakah perusahaan ini efisien dalam memanfaatkan aktivitasnya dalam kegiatan operasional perusahaan. Rasio ini juga memberikan ukuran yang lebih baik atas profitabilitas perusahaan karena menunjukkan efektivitas manajemen dalam mengguanakan aktiva untuk memperoleh pendapatan.

Return on Assets dapat dihitung dengan rumus:

\begin{tabular}{c} 
ROA $=$ Laba bersih \\
Total aktiva \\
\hline
\end{tabular}

\section{5) Return on Equity}

Rasio ini berguna untuk mengetahui besarnya kembalian yang diberikan oleh perusahaan untuk setiap rupiah modal dari pemilik. Rasio ini menunjukkan kesuksesan manajemen dalam memaksimalkan tingkat kembalian pada pemegang saham.

Return on Equity dapat dihitung dengan rumus:

\begin{tabular}{c} 
ROE $=$ Laba bersih \\
Rata--ata ekuitas \\
\hline
\end{tabular}

Rasio ini menggambarkan besarnya pengembalian modal untuk setiap satu lembar saham.

Earning Per Share dapat dihitung dengan rumus:

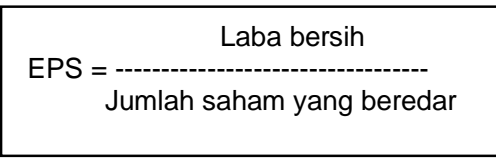

\section{7) Payout Ratio}

Rasio ini menggambarkan persentase dividen kas yang diterima oleh pemegang saham terhadap laba bersih yang diperoleh perusahaan.Rasio ini memberikan gambaran yang lebih baik terhadap keuntungan yang diperoleh pemegang saham dibandingkan dengan keuntungan yang diperoleh perusahaan.

Payout Ratio dapat dihitung dengan rumus:

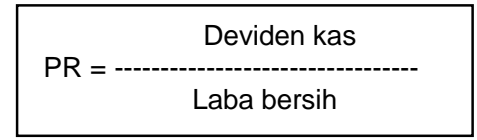

8) Retention Ratio

Retention ratio ditambah dengan payout ratio sama dengan satu. Rasio ini menggambarkan persentase laba bersih yang digunakan untuk penambahan modal perusahaan. 
Retention Ratio dapat dihitung dengan rumus:

\begin{tabular}{|cc|}
\hline $\mathrm{RR}=\quad$ Laba ditahan tahun berjalan \\
Laba bersih \\
\hline
\end{tabular}

9) Productivity ratio

Rasio ini menggambarkan kemampuan operasional perusahaan dalam menjual dengan menggunakan aktiva yang dimiliki. Productivity Ratio dapat dihitung dengan rumus:

$$
\begin{array}{|c|}
\hline \text { PR }=\text { Penjualan bersih } \\
\text { Rata-rata aktiva } \\
\hline
\end{array}
$$

Rasio keuangan yang digunakan untuk memprediksi pertumbuhan laba pada penelitian ini yaitu Debt to Equity Ratio (DER) sebagai sebagai indikator dari rasio laverage, Current Ratio (CR) sebagai indikator dari rasio likuiditas, Total Assets Turn Over (TATO) sebagai indikator dari rasio aktivitas dan Return on Assets (ROA) sebagai indikator dari rasio profitabilitas.

Hubungan Debt to Equity Ratio, Current Ratio, Total Assets Turn Over dan Return on Assets dengan Pertumbuhan Laba Hubungan Debt ti Equity Ratio (DER) dengan Pertumbuhan Laba

DER merupakan salah satu rasio solvabilitas. DER menunjukkan perbandingan antara total hutang dengan modal sendiri.

Semakin tinggi DER menunjukkan semakin tinggi penggunaan hutang sebagai sumber pendanaan perusahaan. Hal ini dapat menimbulkan resiko yang cukup besar bagi perusahaan ketika perusahaan tidak mampu membayar kewajiban tersebut pada saat jatuh tempo, sehingga akan mengganggu kontinuitas operasi perusahaan. Selain itu, perusahaan akan dihadapkan pada biaya bunga yang tinggi sehingga dapat menurunkan laba perusahaan. Hal ini didukung oleh penelitian Indarti (2000) yang menunjukkan bahwa DER berpengaruh negatif terhadap pertumbuhan laba.
Hubungan Working Capital to Total Assets (WCTA) dengan Pertumbuhan Laba

WCTA merupakan salah satu rasio likuiditas. Rasio likuiditas menunjukkan kemampuan perusahaan dalam menggunakan aktiva lancar perusahaan, sehingga mampu membayar utang jangka pendeknya tepat pada waktu yang dibutuhkan.

WCTA yang semakin tinggi menunjukkan modal operasional perusahaan besar dibandingkan dengan jumlah aktivanya (total assets). Modal kerja yang besar akan memperlancar kegiatan operasi perusahaan sehingga perusahaan mampu membayar hutangnya, dengan demikian pendapatan yang diperoleh meningkat. Semakin besar WCTA akan meningkatkan laba yang selanjutnya akan mempengaruhi peningkatan pertumbuhan laba. Hal ini dikarenakan efisiensi dari selisih antara aktiva lancar (current assets) dan hutang lancar (current liabilities). Hasil penelitian Takarini dan Ekawati (2003) menunjukkan bahwa WCTA berpengaruh positif terhadap pertumbuhan laba satu tahun yang akan datang.

Hubungan Total Assets Turn Over (TAT0) dengan Pertumbuhan Laba

TATO merupakan salah satu rasio aktivitas. TATO menunjukkan efisiensi penggunaan seluruh aktiva (total assets) perusahaan untuk menunjang penjualan (sales).

Semakin besar TATO menunjukkan perusahaan efisien dalam menggunakan seluruh aktiva perusahaan untuk menghasilkan penjualan bersihnya. Semakin cepat perputaran aktiva suatu perusahaan untuk menunjang kegiatan penjualan bersihnya, maka pendapatan yang diperoleh meningkat sehingga laba yang didapat besar. Ini didukung oleh Asyik dan Soelistyo (2000) yang dalam penelitiannya menunjukkan bahwa TATO berpengaruh positif terhadap pertumbuhan laba.

Hubungan Net Profit Margin (NPM) dengan Pertumbuhan Laba

NPM termasuk salah satu rasio profitabilitas. NPM menunjukkan kemampuan 
perusahaan dalam menghasilkan pendapatan bersihnya terhadap total penjualan bersihnya. NPM yang semakin besar menunjukkan bahwa semakin besar laba bersih yang diperoleh perusahaan dari kegiatan penjualan. Dengan laba bersih yang besar, bertambah luas kesempatan bagi perusahaan untuk memperbesar modal usahanya tanpa melalui hutang-hutang baru, sehingga pendapatan yang diperoleh menjadi meningkat. Hal ini didukung Suwarno (2004) dan Asyik dan Soelistyo (2000) yang dalam penelitiannya menunjukkan bahwa NPM berpengaruh positif dan signifikan terhadap pertumbuhan laba satu tahun ke depan.

\section{METODE PENELITIAN}

Penelitian ini akan dilaksanakan pada Distributor Prima Palopo dengan alokasi waktu pelaksanaan pelenitian selama 2 (dua) bulan yaitu dari bulan Februari sampai dengan bulan April 2015.

\section{Jenis dan Sumber Data}

Sumber data yang digunakan dalam penelitian ini terdiri dari dua macam yaitu data primer dan data sekunder.

\section{Populasi dan Sampel}

Populasi dan penelitian ini adalah laporan keuangan Distibutor Prima Palopo sejak berdirinya hingga tahun pengambilan data yaitu tahun 2014. Sedangkan sampel dalam penelitian ini yaitu laporan keuangan Distributor Prima Palopo selama 7 tahun terakhir yaitu tahun 2008-2014.

\section{Metode Analisis Data}

Penelitian ini menggunakan analisis data kuantitatif dengan penekanan pada hal yang berhubungan dengan angka dan rumus tertentu dengan menggunakan metode analisis laporan keuangan. Adapun metode analisis laporan keuangan yang digunakan yaitu:

1. Analisis Pertumbuhan Laba

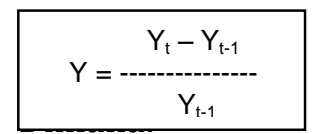

$\mathrm{Y} \quad=$ Pertumbuhan laba
$\mathrm{Y}_{\mathrm{t}} \quad=$ Laba Tahun yang dihitung

$\mathrm{Y}_{\mathrm{t}-1} \quad=$ Laba Tahun Sebelumnya

2. Analisis Rasio Keuangan

a. Debt to Equity Ratio (DER)

\begin{tabular}{|c|}
\hline DER $=-$ Total kewajiban \\
Total ekuitas \\
\hline
\end{tabular}

b. Working Capital to Total Assets (WCTA)

\begin{tabular}{c} 
Aktiva Lancar-kewajiban lancar \\
WCTA $=$---------------------- \\
Jumlah Aktiva \\
\hline
\end{tabular}

c. Total Assets Turn Over (TATO)

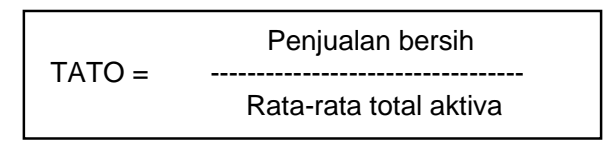

d. Net Profit Margin (NPM)

\begin{tabular}{|c|c|}
\hline \multirow{2}{*}{$\mathrm{NPM}=$} & Laba bersih \\
\hline & Penjualan bersih \\
\hline
\end{tabular}

Analisis Regresi Linier Berganda

Analisis regresi linear berganda yang bertujuan untuk mengukur kekuatan asosiasi (hubungan) linear antara dua variabel atau lebih. Menurut Riduwan dan Akdom (2007:142), adapun model yang digunakan dari regresi linear berganda yaitu menggunakan rumus sebagai berikut :

$$
\mathrm{Y}=\mathrm{a}+\mathrm{b}_{1} \mathrm{X}_{1}+\mathrm{b}_{2} \mathrm{X}_{2}++\mathrm{b}_{3} \mathrm{X}_{3}+\mathrm{b}_{4} \mathrm{X}_{4}+\mathrm{e}
$$

Dimana:

$\mathrm{Y}=$ Pertumbuhan laba

$\mathrm{X}_{1} \quad=$ Working Capital to Total Assets

$\mathrm{X}_{2} \quad=$ Debt to Equity Ratio

$\mathrm{X}_{3} \quad=$ Total Assets Turnover

$\mathrm{X}_{4} \quad=$ Net Profit Margin

a $\quad=$ Konstanta

$\mathrm{e} \quad=$ variabel pengganggu

\section{HASIL DAN PEMBAHASAN}

\section{Penyajian Data Penelitian}

Untuk keperluan analisis dan pembahasan di dalam penulisan ini, maka diperlukan data keuangan Distributor Prima Palopo. Laporan keuangan yang diambil dan dianalisis adalah laporan keuangan periode tahun 2010 dan 2014.

Laporan Laba Rugi Distributor Prima Palopo dapat kita ketahui jumlah pendapatan operasional atau penjualan, beban usaha ditambah pajak penghasilan dan jumlah laba 
usaha yang dihasilkan oleh Distributor Prima Palopo selama 5 tahun yaitu dari tahun 2010 sampai dengan tahun 2014.

Pada tahun 2010 jumlah pendapatan operasional atau penjualan Distributor Prima Palopo sebesar Rp. 383.000.000,-. Jumlah beban usaha ditambah pajak penghasilan Distributor Prima Palopo sebesar Rp. 81.950.000,-, sehingga laba usaha bersih yang diperoleh oleh Distributor Prima Palopo pada tahun 2010 sebesar Rp. 301.050.000,-.

Pada tahun 2011 jumlah pendapatan operasional atau penjualan Distributor Prima Palopo sebesar Rp. 460.550.000,-. Jumlah beban usaha ditambah pajak penghasilan Distributor Prima Palopo sebesar Rp. 84.305.000,-, sehingga laba usaha bersih yang diperoleh oleh Distributor Prima Palopo pada tahun 2011 sebesar Rp. 376.245.000,-.

Pada tahun 2012 jumlah pendapatan operasional atau penjualan Distributor Prima Palopo sebesar Rp. 573.200.750,-. Jumlah beban usaha ditambah pajak penghasilan Distributor Prima Palopo sebesar Rp. 100.047.575,-, sehingga laba usaha bersih yang diperoleh oleh Distributor Prima Palopo pada tahun 2012 sebesar Rp. 473.153.175,-.

Pada tahun 2013 jumlah pendapatan operasional atau penjualan Distributor Prima Palopo sebesar Rp. 749.899.750,-. Jumlah beban usaha ditambah pajak penghasilan Distributor Prima Palopo sebesar Rp. 121.834.975,-, sehingga laba usaha bersih yang diperoleh oleh Distributor Prima Palopo pada tahun 2013 sebesar Rp. 628.640.950,-.

Pada tahun 2014 jumlah pendapatan operasional atau penjualan Distributor Prima Palopo sebesar Rp. 1.022.500.000,-. Jumlah beban usaha ditambah pajak penghasilan Distributor Prima Palopo sebesar Rp. 148.640.950,-, sehingga laba usaha bersih yang diperoleh oleh Distributor Prima Palopo pada tahun 2014 sebesar Rp. 873.859.050,-.

Peningkatan laba yang dihasilkan oleh Distributor Prima Palopo terjadi akibat adanya peningkatan pendapatan dari usaha yang dilakukan oleh Distributor Prima Palopo.
Neraca Distributor Prima Palopo tahun 2010 sampai dengan tahun 2014 yang menggambarkan tentang jumlah aktiva, utang dan modal yang dimiliki oleh Distributor Prima Palopo selama 5 tahun yaitu dari tahun 2010 sampai dengan tahun 2014.

Pada tahun 2010 total aktiva yang dimiliki oleh Distributor Prima Palopo sebesar Rp. 628.500.000,-, sedangkan utang yang dimiliki oleh Distributor Prima Palopo sebesar Rp. 298.000.000,- dan jumlah modal yang dimiliki oleh Distributor Prima Palopo sebesar Rp.330.500.00,-.

Pada tahun 2011 total aktiva yang dimiliki oleh Distributor Prima Palopo sebesar Rp. 654.550.250,-, sedangkan utang yang dimiliki oleh Distributor Prima Palopo sebesar Rp. 339.000.000,- dan jumlah modal yang dimiliki oleh Distributor Prima Palopo sebesar Rp. 315.550.250,-.

Pada tahun 2012 total aktiva yang dimiliki oleh Distributor Prima Palopo sebesar Rp. 662.750.250,-, sedangkan utang yang dimiliki oleh Distributor Prima Palopo sebesar Rp. 384.000.000,- dan jumlah modal yang dimiliki oleh Distributor Prima Palopo sebesar Rp. 278.750.250,-.

Pada tahun 2013 total aktiva yang dimiliki oleh Distributor Prima Palopo sebesar Rp. 666.275.000,-, sedangkan utang yang dimiliki oleh Distributor Prima Palopo sebesar Rp. 395.000.000,- dan jumlah modal yang dimiliki oleh Distributor Prima Palopo sebesar Rp. 271.275.000,-.

Pada tahun 2014 total aktiva yang dimiliki oleh Distributor Prima Palopo sebesar Rp. 657.555.000,-, sedangkan utang yang dimiliki oleh Distributor Prima Palopo sebesar Rp. 390.000.000,- dan jumlah modal yang dimiliki oleh Distributor Prima Palopo sebesar Rp. 267.555.000,--

\section{Analisis Data Penelitian}

Untuk mengetahui bagaimana penggunaan rasio keuangan dalam memprediksi pertumbuhan laba pada Distributor Prima Palopo, maka dilakukan analisis data sebagai berikut: 


\section{Analisis Pertumbuhan Laba}

Pertumbuhan laba $(Y)=\frac{Y_{t}-Y_{t-1}}{Y_{t-1}}$

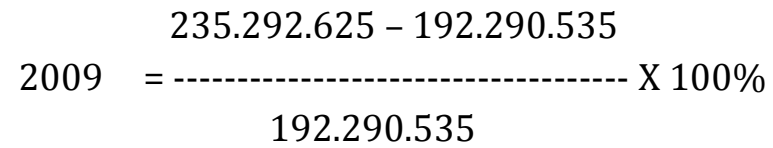

$=22 \%$

Pada tahun 2009 diketahui bahwa pertumbuhan laba pada Distributor Prima Kota Palopo sebesar 22\% artinya bahwa Distributor Prima Palopo mampu memperoleh peningkatan laba pada tahun 2009 sebesar $22 \%$ dari laba tahun sebelumnya.

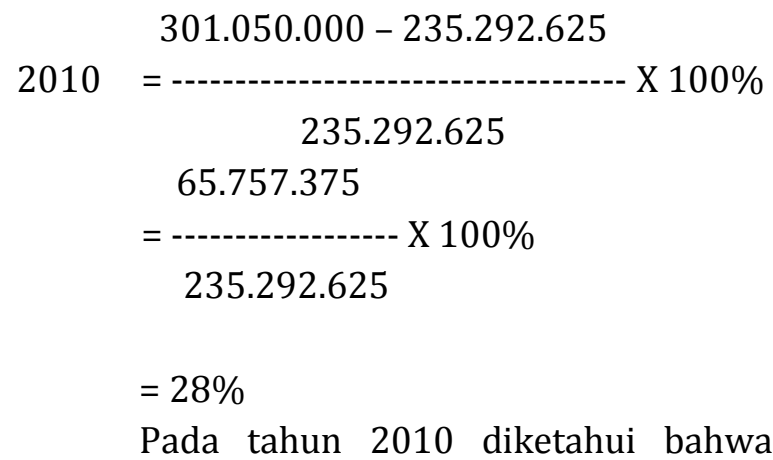
pertumbuhan laba pada Distributor Prima Kota Palopo sebesar 28\% artinya bahwa Distributor Prima Palopo mampu memperoleh peningkatan laba pada tahun 2010 sebesar $28 \%$ dari laba tahun sebelumnya.

$$
376.245 .000-301.050 .000
$$

2011

= 301.050 .000

$$
\begin{aligned}
& \begin{array}{l}
75.195 .000 \\
=
\end{array} \\
& 301.050 .000 \\
= & 25 \%
\end{aligned}
$$

Pada tahun 2011 diketahui bahwa pertumbuhan laba pada Distributor Prima Kota Palopo sebesar 25\% artinya bahwa Distributor Prima Palopo mampu memperoleh

peningkatan laba pada tahun 2011 sebesar $25 \%$ dari laba tahun sebelumnya.

$473.153 .175-376.245 .000$

201 X $100 \%$

376.245 .000

96.908 .175

376.245 .000

$$
=26 \%
$$

Pada tahun 2012 diketahui bahwa pertumbuhan laba pada Distributor Prima Kota Palopo sebesar 26\% artinya bahwa Distributor Prima Palopo mampu memperoleh peningkatan laba pada tahun 2012 sebesar $26 \%$ dari laba tahun sebelumnya.

$$
628.064 .775-473.153 .175
$$

2013

$\begin{aligned} & 473.153 .175 \\ & 154.911 .600 \\ = & ----------- \text { X 100\% } \\ & 473.153 .175 \\ = & 33 \%\end{aligned}$

Pada tahun 2013 diketahui bahwa pertumbuhan laba pada Distributor Prima Kota Palopo sebesar 33\% artinya bahwa Distributor Prima Palopo mampu memperoleh peningkatan laba pada tahun 2013 sebesar $33 \%$ dari laba tahun sebelumnya.

$$
873.859 .050-628.064 .775
$$

2014

$\begin{aligned} & 628.064 .775 \\ & 245.794 .275 \\ &=-87300 \\ & 628.064 .775 \\ &= 39 \% \\ & \text { Pada tahun } 2014 \text { diketahui bahwa }\end{aligned}$
pertumbuhan laba pada Distributor Prima Kota Palopo sebesar 39\% artinya bahwa Distributor Prima Palopo mampu memperoleh peningkatan laba pada tahun 2014 sebesar 39\% dari laba tahun sebelumnya.

\section{Analisis Rasio Keuangan}

1) Debt to Equity Ratio (DER)

Total kewajiban

$$
\begin{gathered}
\text { DER }=0 \text { Total ekuitas } \\
155.000 .000
\end{gathered}
$$




$$
\begin{aligned}
2008 & =-1 .-0.471 .000 \\
& 460
\end{aligned}
$$

Dari perhitungan Debt to Equity Ratio (DER), diperoleh Debt to Equity Ratio (DER) pada tahun 2008 sebesar 34\%. Hal ini berarti bahwa pada tahun 2008 Distributor Prima Kota Palopo menyediakan sekitar 34\% dari modal yang dimilikinya untuk menutupi kewajbannya.

195.000.000

$$
\begin{aligned}
2009= & -------X^{2} 100 \% \\
= & 46 \%
\end{aligned}
$$

Dari perhitungan Debt to Equity Ratio (DER), diperoleh Debt to Equity Ratio (DER) pada tahun 2009 sebesar 46\%. Hal ini berarti bahwa pada tahun 2009 Distributor Prima Kota Palopo menyediakan sekitar 46\% dari modal yang dimilikinya untuk menutupi kewajbannya.

$$
\begin{aligned}
2010= & 298.000 .000 \\
- & 330.500 .000 \\
= & 90 \%
\end{aligned}
$$

Dari perhitungan Debt to Equity Ratio (DER), diperoleh Debt to Equity Ratio (DER) pada tahun 2010 sebesar 90\%. Hal ini berarti bahwa pada tahun 2010 Distributor Prima2) Kota Palopo menyediakan sekitar 90\% dari modal yang dimilikinya untuk menutupi kewajbannya.

$$
\begin{aligned}
& 339.000 .000 \\
= & -315.550 .250 \\
= & 107 \%
\end{aligned}
$$

Dari perhitungan Debt to Equity Ratio (DER), diperoleh Debt to Equity Ratio (DER) pada tahun 2011 sebesar 107\%. Hal ini berarti bahwa pada tahun 2011 Distributor Prima Kota Palopo menyediakan sekitar $107 \%$ dari modal yang dimilikinya untuk menutupi kewajbannya.

$$
\begin{aligned}
2012= & 384.000 .000 \\
\hdashline & 278.750 .250 \\
= & 138 \%
\end{aligned}
$$

Dari perhitungan Debt to Equity Ratio (DER), diperoleh Debt to Equity Ratio (DER) pada tahun 2012 sebesar 138\%. Hal ini berarti bahwa pada tahun 2012 Distributor Prima Kota Palopo menyediakan sekitar 138\% dari modal yang dimilikinya untuk menutupi kewajbannya.

$$
395.000 .000
$$

$$
\begin{aligned}
2013= & --------X^{2} 100 \% \\
& 271.275 .000 \\
= & 146 \%
\end{aligned}
$$

Dari perhitungan Debt to Equity Ratio (DER), diperoleh Debt to Equity Ratio (DER) pada tahun 2013 sebesar 146\%. Hal ini berarti bahwa pada tahun 2013 Distributor Prima Kota Palopo menyediakan sekitar 146\% dari modal yang dimilikinya untuk menutupi kewajbannya.

$$
\begin{aligned}
& 2014= 390.000 .000 \\
& 267.555 .000 \\
&= 146 \% \\
& \text { Dari perhitungan Debt to Equity Ratio }
\end{aligned}
$$
(DER), diperoleh Debt to Equity Ratio (DER) pada tahun 2014 sebesar 146\%. Hal ini berarti bahwa pada tahun 2014 Distributor Prima Kota Palopo menyediakan sekitar 146\% dari modal yang dimilikinya untuk menutupi kewajbannya.

Working Capital to Total Assets (WCTA)

Aktiva Lancar-kewajiban lancar

$$
\begin{aligned}
& \text { WCTA }= \multicolumn{1}{c}{\text { Jumlah Aktiva }} \\
& 187.471 .000-55.000 .000 \\
& 2008= 615.471 .000 \\
& 132.471 .000 \\
&= \\
& 615.471 .000 \\
&= 22 \% \\
& \text { Dari perhitungan Wprking Capital to }
\end{aligned}
$$
Total Assets pada tahun 2008 diperoleh Working Capital to Total Assets sebesar 22\%. Hal ini berarti bahwa Distributor Prima Kota Palopo memiliki kemampuan sebesar 22\% dengan aktiva lancar yang dimilikinya untuk melunasi kewajiban jangka pendeknya. 


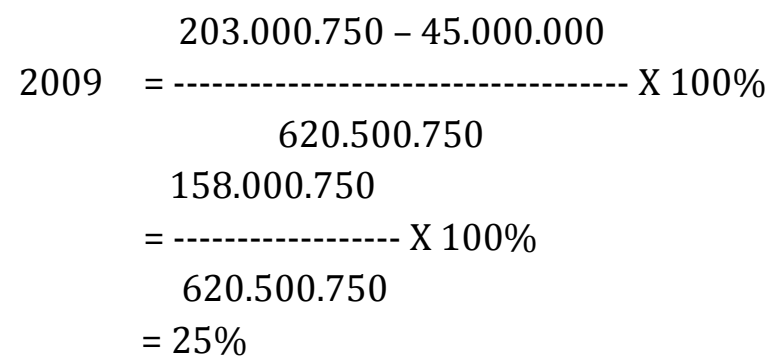

Dari perhitungan Wprking Capital to Total Assets pada tahun 2009 diperoleh Working Capital to Total Assets sebesar 25\%. Hal ini berarti bahwa Distributor Prima Kota Palopo memiliki kemampuan sebesar 25\% dengan aktiva lancar yang dimilikinya untuk melunasi kewajiban jangka pendeknya.

$218.500 .000-98.000 .0000$

\begin{aligned} $2010= & 628.500 .000 \\ & 120.500 .000 \\ = & \\$\hdashline & 628.500 .000 \\ $= & 19 \%\end{aligned}$

Dari perhitungan Wprking Capital to Total Assets pada tahun 2010 diperoleh Working Capital to Total Assets sebesar 19\%. Hal ini berarti bahwa Distributor Prima Kota Palopo memiliki kemampuan sebesar 19\% dengan aktiva lancar yang dimilikinya untuk melunasi kewajiban jangka pendeknya.

\begin{aligned} & $2011= 237.000 .000-89.000 .000 \\ & \multicolumn{1}{c}{654.550 .250} \\ &= 148.000 .000 \\ & 654.550 .250 \\ &= 23 \% \\ &$ Dari perhitungan Wprking Capital to \end{aligned}

Total Assets pada tahun 2011 diperoleh3) Working Capital to Total Assets sebesar 23\%. Hal ini berarti bahwa Distributor Prima Kota Palopo memiliki kemampuan sebesar 23\% dengan aktiva lancar yang dimilikinya untuk melunasi kewajiban jangka pendeknya.

$241.750 .250-99.000 .000$

$\begin{aligned} 2012= & 662.750 .250 \\ & 142.750 .250 \\ = & 662.750 .250\end{aligned}$

$$
=22 \%
$$

Dari perhitungan Wprking Capital to Total Assets pada tahun 2012 diperoleh Working Capital to Total Assets sebesar 22\%. Hal ini berarti bahwa Distributor Prima Kota Palopo memiliki kemampuan sebesar 22\% dengan aktiva lancar yang dimilikinya untuk melunasi kewajiban jangka pendeknya.

$$
244.250 .000-100.000 .000
$$

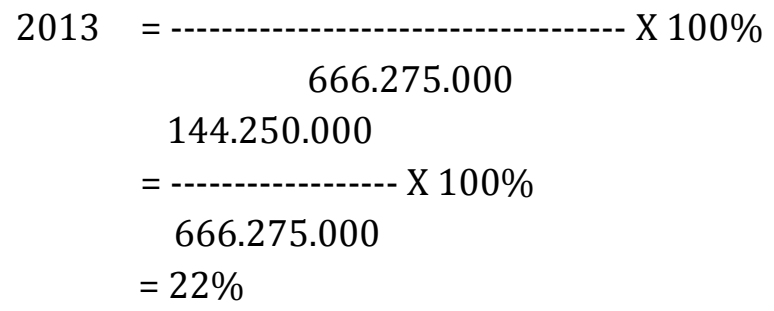

Dari perhitungan Working Capital to Total Assets pada tahun 2013 diperoleh Working Capital to Total Assets sebesar 22\%. Hal ini berarti bahwa Distributor Prima Kota Palopo memiliki kemampuan sebesar 22\% dengan aktiva lancar yang dimilikinya untuk melunasi kewajiban jangka pendeknya.

$276.050 .000-115.000 .000$

\begin{aligned} & $2014= \multicolumn{1}{c}{657.555 .000} \\ & 161.050 .000 \\ &=-100 \% \\ & 657.555 .000 \\ &= 24 \% \\ &$ Dari perhitungan Working Capital to \end{aligned} Total Assets pada tahun 2014 diperoleh Working Capital to Total Assets sebesar 24\%. Hal ini berarti bahwa Distributor Prima Kota Palopo memiliki kemampuan sebesar 24\% dengan aktiva lancar yang dimilikinya untuk melunasi kewajiban jangka pendeknya.

Total Assets Turn Over (TATO)

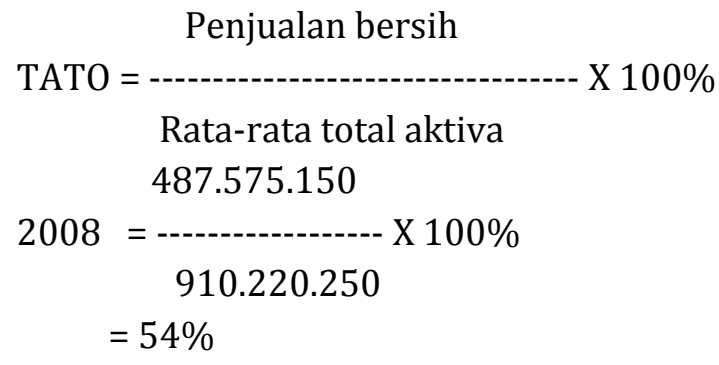

Dari perhitungan Total Assets Turn Over, diperoleh Total Assets Turn Over pada tahun 2008 sebesar $54 \%$. Hal ini berarti bahwa 
pada tahun 2008 Distributor Prima Kota Palopo memiiki kemampuan sebesar 54\% dalam mengefisienkan aktiva yang dimilikinya untuk meningkatkan penjualan yang dilakukannya.

$$
\begin{aligned}
& \text { 509.798.000 } \\
& 2009= \\
& 928.236 .250 \\
& =55 \%
\end{aligned}
$$

Dari perhitungan Total Assets Turn Over, diperoleh Total Assets Turn Over pada tahun 2009 sebesar 55\%. Hal ini berarti bahwa pada tahun 2009 Distributor Prima Kota Palopo memiiki kemampuan sebesar 55\% dalam mengefisienkan aktiva yang dimilikinya untuk meningkatkan penjualan yang dilakukannya.

$$
\begin{aligned}
& 688.000 .000 \\
2010= & 934.750 .750 \\
= & 74 \%
\end{aligned}
$$

Dari perhitungan Total Assets Turn Over, diperoleh Total Assets Turn Over pada tahun 2010 sebesar 74\%. Hal ini berarti bahwa pada tahun 2010 Distributor Prima Kota Palopo memiiki kemampuan sebesar $74 \%$ dalam mengefisienkan aktiva yang dimilikinya untuk meningkatkan penjualan yang dilakukannya.

$$
\begin{aligned}
& 767.750 .000 \\
&=--955.775 .125 \\
&= 80 \% \\
& \text { Dari perhitungan Total Assets Turn }
\end{aligned}
$$

Over, diperoleh Total Assets Turn Over pada tahun 2011 sebesar 80\%. Hal ini berarti bahwa pada tahun 2011 Distributor Prima Kota Palopo memiiki kemampuan sebesar $80 \%$ dalam mengefisienkan aktiva yang dimilikinya untuk meningkatkan penjualan yang dilakukannya. 895.150 .500

$$
\begin{aligned}
& 2012= \\
& 985.925 .375 \\
& =91 \% \\
& \text { Dari perhitungan Total Assets Turn }
\end{aligned}
$$

Over, diperoleh Total Assets Turn Over pada tahun 2012 sebesar $91 \%$. Hal ini berarti bahwa pada tahun 2012 Distributor Prima Kota Palopo memiiki kemampuan sebesar 91\% dalam mengefisienkan aktiva yang dimilikinya untuk meningkatkan penjualan yang dilakukannya.

$2013=-1.052 .450 .000$
$=106 \%$

Dari perhitungan Total Assets Turn Over, diperoleh Total Assets Turn Over pada tahun 2013 sebesar 106\%. Hal ini berarti bahwa pada tahun 2013 Distributor Prima Kota Palopo memiiki kemampuan sebesar $106 \%$ dalam mengefisienkan aktiva yang dimilikinya untuk meningkatkan penjualan yang dilakukannya.

$2014=-1.370 .500 .000$
$=138 \%$

Dari perhitungan Total Assets Turn Over, diperoleh Total Assets Turn Over pada tahun 2014 sebesar 138\%. Hal ini berarti bahwa pada tahun 2014 Distributor Prima Kota Palopo memiiki kemampuan sebesar $138 \%$ dalam mengefisienkan aktiva yang dimilikinya untuk meningkatkan penjualan yang dilakukannya.

4) Net Profit Margin (NPM)

Laba bersih

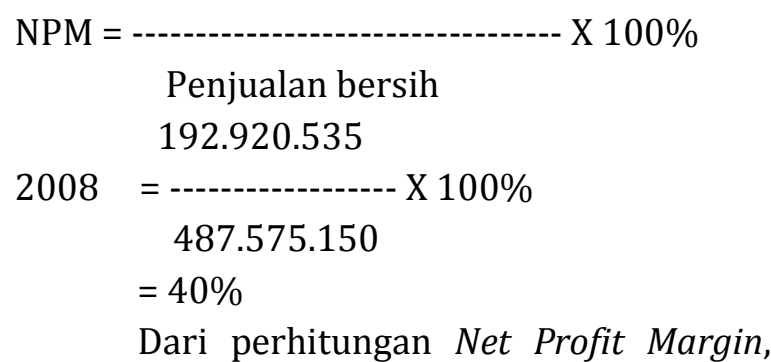
diperoleh Net Profit Margin pada tahun 2008 sebesar 40\%. Hal ini berarti bahwa pada tahun 2008 Distributor Prima Kota Palopo memiiki kemampuan sebesar $40 \%$ untuk memperoleh laba bersih dari kegiatan penjualannya.

235.292.625

$\begin{aligned} 2009= & -109.798 .000 \\ = & 46 \%\end{aligned}$


Dari perhitungan Net Profit Margin, diperoleh Net Profit Margin pada tahun 2009 sebesar 46\%. Hal ini berarti bahwa pada tahun 2009 Distributor Prima Kota Palopo memiiki kemampuan sebesar 46\% untuk memperoleh laba bersih dari kegiatan penjualannya.

301.050 .000

$$
\begin{aligned}
2010= & 688.000 .000 \\
= & 44 \%
\end{aligned}
$$

Dari perhitungan Net Profit Margin, diperoleh Net Profit Margin pada tahun 2010 sebesar 44\%. Hal ini berarti bahwa pada tahun 2010 Distributor Prima Kota Palopo memiiki kemampuan sebesar 44\% untuk memperoleh laba bersih dari kegiatan penjualannya.

376.245 .000

$$
\begin{aligned}
& 2011=------ \text { X 100\% } \\
& 767.750 .000 \\
& =49 \%
\end{aligned}
$$

Dari perhitungan Net Profit Margin, diperoleh Net Profit Margin pada tahun 2011 sebesar 49\%. Hal ini berarti bahwa pada tahun 201 Distributor Prima Kota Palopo memiiki kemampuan sebesar 49\% untuk memperoleh laba bersih dari kegiatan penjualannya.

473.153.175

$$
\begin{aligned}
& 2012= \\
& \text { 895.150.500 } \\
& =53 \%
\end{aligned}
$$

Dari perhitungan Net Profit Margin, diperoleh Net Profit Margin pada tahun 2012 sebesar 53\%. Hal ini berarti bahwa pada tahun 2012 Distributor Prima Kota Palopo memiiki kemampuan sebesar 53\% untuk memperoleh laba bersih dari kegiatan penjualannya. 628.064 .775

$$
\begin{aligned}
2013= & -1.052 .450 .000 \\
& =60 \%
\end{aligned}
$$

Dari perhitungan Net Profit Margin, diperoleh Net Profit Margin pada tahun 2013 sebesar $60 \%$. Hal ini berarti bahwa pada tahun 2013 Distributor Prima Kota Palopo memiiki kemampuan sebesar $60 \%$ untuk memperoleh laba bersih dari kegiatan penjualannya.

873.859 .050

$$
\begin{aligned}
2014= & --------------- \text { X 100\% } \\
& 1.370 .500 .000 \\
= & 64 \%
\end{aligned}
$$

Dari perhitungan Net Profit Margin, diperoleh Net Profit Margin pada tahun 2014 sebesar 64\%. Hal ini berarti bahwa pada tahun 2014 Distributor Prima Kota Palopo memiiki kemampuan sebesar 64\% untuk memperoleh laba bersih dari kegiatan penjualannya.

Untuk lebih jelasnya, tentang data penelitian berdasarkan analisis deskriptif di atas, dapat dilihat pada Tabel 4.3 berikut:

Tabel .1 Data Penelitian

\begin{tabular}{|c|c|c|c|c|c|}
\hline \multirow{2}{*}{ Tahun } & \multicolumn{4}{|c|}{ Rasio Keuangan } & Pertumbuhan \\
\cline { 2 - 5 } & DER & WCTA & TAT0 & NPM & Laba \\
\hline 2008 & $34 \%$ & $22 \%$ & $54 \%$ & $40 \%$ & - \\
\hline 2009 & $46 \%$ & $25 \%$ & $55 \%$ & $46 \%$ & $22 \%$ \\
\hline 2010 & $90 \%$ & $19 \%$ & $74 \%$ & $44 \%$ & $28 \%$ \\
\hline 2011 & $107 \%$ & $23 \%$ & $80 \%$ & $49 \%$ & $25 \%$ \\
\hline 2012 & $138 \%$ & $22 \%$ & $91 \%$ & $53 \%$ & $26 \%$ \\
\hline 2013 & $146 \%$ & $22 \%$ & $106 \%$ & $60 \%$ & $33 \%$ \\
\hline 2014 & $146 \%$ & $24 \%$ & $138 \%$ & $64 \%$ & $39 \%$ \\
\hline
\end{tabular}

Sumber: Data Diolah, 2015

\section{a. Analisis Regresi Linier Berganda}

Analisis regresi linear berganda yang bertujuan untuk mengukur kekuatan asosiasi (hubungan) linear antara dua variabel atau lebih.

Coefficients dapat diperoleh persamaan regresi linear berganda sebagai berikut:

$\mathrm{Y}=0,003+0.021 \mathrm{X}_{1}-1,586 \mathrm{X}_{2}-0,479 \mathrm{X}_{3}+$ $2,023 \mathrm{X}_{4}+\mathrm{e}$

Dari persamaan regresi linear berganda di atas dapat diperoleh kesimpulan sebagai berikut:

a. Apabila debt to equity ratio, working capital to total assets ratio, total assets turn over ratio dan net profit margin ratio nilainya adalah 0 maka pertumbuhan laba pada Distributor Prima Palopo nilainya sebesar 0,003\%,-.

b. Apabila debt to equity ratio nilainya dinaikkan sebesar 1\%,- maka akan mempengaruhi peningkatan nilai pertumbuhan laba pada Distributor Prima 
Palopo sebesar 0,021\%,-. Dengan katan lain debt to equity ratio berpengaruh postif dalam mempredeksi pertumbuhan laba pada Distributor Prima Palopo.

c. Apabila working capital to total assets ratio nilainya dinaikkan sebesar $1 \%$, maka akan mempengaruhi penurunan nilai pertumbuhan laba sebesar 1,586\%. Dengan katan lain working capital to total assets ratio berpengaruh negatif dalam mempredeksi pertumbuhan laba pada Distributor Prima Palopo.

d. Apabila total assets turn over ratio nilainya dinaikkan sebesar 1\%, maka akan mempengaruhi penurunan nilai pertumbuhan laba sebesar 0,479\%. Dengan katan lain total assets turn over ratio berpengaruh negatif dalam mempredeksi pertumbuhan laba pada Distributor Prima Palopo.

e. Apabila net profit margin ratio nilainya dinaikkan sebesar $\quad 1 \%$, maka akan mempengaruhi peningkatan nilai pertumbuhan laba pada Distributor Prima Palopo sebesar 2,023\%. Dengan katan lain net profit margin ratio berpengaruh postif dalam mempredeksi pertumbuhan laba pada Distributor Prima Palopo.

\section{b. Analisis Koefisien Determinasi}

Analisis $\mathrm{R}^{2}$ ( $\mathrm{R}$ Square) atau koefisien determinasi digunakan untuk mengetahui seberapa besar persentase pengaruh rasio keuangan yang terdiri dari debt to equity ratio, working capital to total assets ratio, total assets turn over ratio dan net profit margin ratio secara bersamasama dalam memprediksi pertumbuhan laba pada Distributor Prima Palopo.
Tabel.2 Model Summary

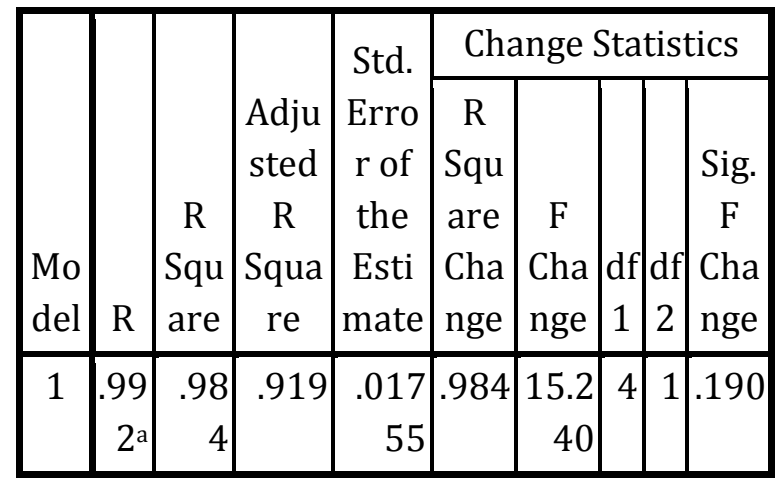

a. Predictors: (Constant), NPM, WCTA, DER,

TATO

Sumber: Data Hasil Olahan SPSS, 2015

Dari diatas Model Summary di atas diketahui nilai $\mathrm{R}^{2}$ (R Square) adalah 0,984 , jadi dapat disimpulkan bahwa rasio keuangan yang terdiri dari debt to equity ratio, working capital to total assets ratio, total assets turn over ratio dan net profit margin ratio secara bersamasama berpengaruh sebesar 98,4\% dalam memprediksi pertumbuhan laba pada Distributor Prima Palopo. Sedangkan sisanya yaitu sebesar 1,6\% dipengaruhi oleh faktor lain yang tidak diteliti pada penelitian ini.

c. Uji F

Uji $F$ digunakan untuk menguji pengaruh secara bersama-sama rasio keuangan yang terdiri dari debt to equity ratio, working capital to total assets ratio, total assets turn over ratio dan net profit margin ratio berpengaruh dalam memprediksi pertumbuhan laba pada Distributor Prima Palopo. Pada penelitian ini, dalam pengambilan keputusan peneliti berdasarkan pada taraf signifikansi 0,05 dengan ketentuan sebagai berikut:

1) Apabila signifikansi lebih dari pada 0,05 berarti rasio keuangan yang terdiri dari debt to equity ratio, working capital to total assets ratio, total assets turn over ratio dan net profit margin ratio tidak berpengaruh signifikan dalam memprediksi pertumbuhan laba pada Distributor Prima Palopo.

2) Apabila signifikansi lebih kecil dari pada 0,05 berarti rasio keuangan yang terdiri dari debt to equity ratio, working capital to 
total assets ratio, total assets turn over ratio dan net profit margin ratio berpengaruh secara signifikan dalam memprediksi pertumbuhan laba pada Distributor Prima Palopo.

Tabel 3

ANOVA $^{\mathrm{b}}$

\begin{tabular}{|c|r|r|r|c|c|}
\hline Model & $\begin{array}{r}\text { Sum of } \\
\text { Squares }\end{array}$ & $\begin{array}{r}\text { df } \\
\text { Sean }\end{array}$ & Square & F & Sig. \\
\hline 1 Regression & .019 & 4 & .005 & 15.240 & $.190 \mathrm{a}$ \\
Residual & .000 & 1 & .000 & & \\
Total & .019 & 5 & & & \\
\hline
\end{tabular}

a. Predictors: (Constant), NPM, WCTA, DER,

TATO

b. Dependent Variable: Pertumbuhan Laba

Sumber: Data Hasil Olahan SPSS, 2015

Dari Tabel.3 Annova di atas diketahui bahwa signifikansi sebesar 0,190 lebih besar dari 0,05 maka dapat disimpulkan bahwa rasio keuangan yang terdiri dari debt to equity ratio, working capital to total assets ratio, total assets turn over ratio dan net profit margin ratio tidak berpengaruh signifikan dalam memprediksi pertumbuhan laba pada Distributor Prima Palopo.

\section{d. Uji t}

Uji t digunakan untuk menguji pengaruh rasio keuangan yang terdiri dari debt to equity ratio, working capital to total assets ratio, total assets turn over ratio dan net profit margin ratio berpengaruh dalam memprediksi pertumbuhan laba pada Distributor Prima Palopo.

Sama halnya pada pengujian uji $\mathrm{F}$ pengambilan keputusan didasarkan pada taraf signifikansi 0,05 dengan ketentuan sebagai berikut:

1) Apabila signifikansi lebih dari pada 0,05 berarti rasio keuangan yang terdiri dari debt to equity ratio, working capital to total assets ratio, total assets turn over ratio dan net profit margin ratio tidak berpengaruh signifikan dalam memprediksi pertumbuhan laba pada Distributor Prima Palopo.
2) Apabila signifikansi lebih kecil dari pada 0,05 berarti rasio keuangan yang terdiri dari debt to equity ratio, working capital to total assets ratio, total assets turn over ratio dan net profit margin ratio berpengaruh secara signifikan dalam memprediksi pertumbuhan laba pada Distributor Prima Palopo.

Dari Tabel Cofficient diketahui bahwa:

1) Untuk debt to equity ratio diperoleh nilai signifikansi sebesar 0,862 lebih besar dari 0,05 maka dapat disimpulkan bahwa debt to equity ratio tidak berpengaruh signifikan dalam memprediksi pertumbuhan laba pada Distributor Prima Palopo.

2) Untuk working capital to total assets ratio diperoleh nilai signifikansi sebesar 0,380 lebih besar dari 0,05 maka dapat disimpulkan bahwa working capital to total assets ratio tidak berpengaruh signifikan dalam memprediksi pertumbuhan laba pada Distributor Prima Palopo.

3) Untuk total assets turn over ratio diperoleh nilai signifikansi sebesar 0,450 lebih besar dari 0,05 maka dapat disimpulkan bahwa total assets turn over ratio tidak berpengaruh signifikan dalam memprediksi pertumbuhan laba pada Distributor Prima Palopo.

4) Untuk net profit margin ratio diperoleh nilai signifikansi sebesar 0,222 lebih besar dari 0,05 maka dapat disimpulkan bahwa net profit margin ratio tidak berpengaruh signifikan dalam memprediksi pertumbuhan laba pada Distributor Prima Palopo.

Berdasarkah hasil analisis tentang rasio keuangan dan pertumbuhan laba dari tahun 2010 sampai dengan tahun 2014, maka dapat dianalisis lebih lanjut untuk memprediksi pertumbuhan laba Distributor Prima Kota Palopo pada tahun 2015. Di mana untuk prediksi pertumbuhan laba pada Distributor Prima Kota Palopo pada tahun 2015 diperoleh sebesar 53,40\%, yang berarti bahwa 
pertumbuhan laba pada Distributor Prima Kota Palopo mengalami peningkatan sebesar 14,40\% dari tahun 2014.

\section{PEMBAHASAN}

Dari analisis data yang telah dilakukan di atas, maka dapat disimpulkan bahwa secara bersama-sama rasio keuangan yang terdiri dari debt to equity ratio, working capital to total assets ratio, total assets turn over ratio dan net profit margin ratio tidak berpengaruh signifikan dalam memprediksi pertumbuhan laba pada Distributor Prima Palopo. Hasil tersebut dibuktikan dengan uji $\mathrm{F}$ dimana diperoleh signifikansi sebesar 0,190 lebih besar dari 0,05 maka dapat disimpulkan bahwa rasio keuangan yang terdiri dari debt to equity ratio, working capital to total assets ratio, total assets turn over ratio dan net profit margin ratio tidak berpengaruh signifikan dalam memprediksi pertumbuhan laba pada Distributor Prima Palopo.

Untuk hasil analisis secara parsial dengan uji t dijabarkan sebagai berikut:

\section{a. Pengaruh Debt to Equity Ratio Dalam Memprediksi Pertumbuhan Laba Pada Distrbutor Prima Palopo}

Berdasarkan hasil analisis data diperoleh koefisien regresi untuk debt to equity ratio bernilai positif $(0,021)$, hal ini menunjukkan bahwa debt to equity ratio berpengaruh positif terhadap pertumbuhan laba pada Distributor Prima Palopo yang berarti bahwa setiap penambahan debt to equity ratio akan mempengaruhi peningkatan pertumbuhan laba pada Distributor Prima. Sedangkan nilai signifikansi sebesar 0,862 lebih besar dari 0,05 yang berarti bahwa debt to equity ratio tidak berpengaruh signifikan dalam memprediksi pertumbuhan laba pada Distibutor Prima Palopo.

b. Pengaruh Working Capital to Total Assets Ratio Dalam Memprediksi Pertumbuhan Laba Pada Distrbutor Prima Palopo

Berdasarkan hasil analisis data diperoleh koefisien regresi untuk working capital to total assets ratio bernilai negatif
$(-1,586)$, hal ini menunjukkan bahwa working capital to total assets ratio berpengaruh negatif terhadap pertumbuhan laba pada Distributor Prima Palopo yang berarti bahwa setiap penambahan working capital to total assets akan mempengaruhi penurunan pertumbuhan laba pada Distributor Prima. Sedangkan nilai signifikansi sebesar 0,380 lebih besar dari 0,05 yang berarti bahwa working capital to total assets ratio tidak berpengaruh signifikan dalam memprediksi pertumbuhan laba pada Distibutor Prima Palopo.

c. Pengaruh Total Assets Turn Over Ratio Dalam Memprediksi Pertumbuhan Laba Pada Distrbutor Prima Palopo

Berdasarkan hasil analisis data diperoleh koefisien regresi untuk total assets turn over ratio bernilai negatif (0,479), hal ini menunjukkan bahwa total assets turn over ratio berpengaruh negatif terhadap pertumbuhan laba pada Distributor Prima Palopo yang berarti bahwa setiap penambahan total assets turn over ratio akan mempengaruhi penurunan pertumbuhan laba pada Distributor Prima. Sedangkan nilai signifikansi sebesar 0,450 lebih besar dari 0,05 yang berarti bahwa total assets turn over ratio tidak berpengaruh signifikan dalam memprediksi pertumbuhan laba pada Distibutor Prima Palopo.

d. Pengaruh Net Profit Margin Ratio Dalam Memprediksi Pertumbuhan Laba Pada Distrbutor Prima Palopo

Berdasarkan hasil analisis data diperoleh koefisien regresi untuk net profit margin ratio bernilai positf $(2,023)$, hal ini menunjukkan bahwa net profit margin ratio berpengaruh positif terhadap pertumbuhan laba pada Distributor Prima Palopo yang berarti bahwa setiap penambahan net profit margin ratio akan mempengaruhi peningkatan pertumbuhan laba pada Distributor Prima. Sedangkan nilai signifikansi sebesar 0,222 lebih besar 
dari 0,05 yang berarti bahwa net profit margin ratio tidak berpengaruh signifikan dalam memprediksi pertumbuhan laba pada Distibutor Prima Palopo.

Untuk perhitungan prediksi pertumbuhan laba berdasarkan rasio keuangan pada Distributor Prima Kota Palopo pada tahun 2015 sebesar 53,40\%, yang berarti bahwa pertumbuhan laba pada Distributor Prima Kota Palopo mengalami peningkatan sebesar $14,40 \%$ dari tahun 2014.

\section{KESIMPULAN}

Berdasarkan hasil analisis data dan pembahasan yang telah dilakukan, dapat disimpulkan hal-hal sebagai berikut:

Dari hasil uji $\mathrm{F}$ dimana diperoleh signifikansi sebesar 0,190 lebih besar dari 0,05, Berdasarkan hasil uji t diperoleh koefisien

\section{DAFTAR PUSTAKA}

Agus Endro Suwarno. 2004. Manfaat Informasi Rasio Keuangan Dalam Memprediksi Perubahan Laba", Jurnal Akuntansi dan keuangan, vol 3:2.

Anoraga dan Pakarti. 2006. Pengantar Pasar Modal. Jakarta: Rineka Cipta.

Anis, Chariri dan Imam Ghozali. 2003. Teori Akuntansi. Semarang: BP UNDIP.

Bambang Riyanto. 2001. Dasar-Dasar Pembelanjaan Perusahaan, Edisi 4. Yogyakarta: BPFE.

Barlian, Ridwan S. 2003. Manajemen Keuangan. Edisi Kelima. Cetakan Kedua. Jakarta: Literata Lintas Media.

Harahap, Sofyan Safri, 2005. Teori Akuntansi Jakarta: PT. Raja Grafindo Persada.

Jumingan. 2006. Analisis Laporan Keuangan. Cetakan Pertama. Jakarta : PT. Bumi Aksara.

Mamduh Hanafi, dan Abdul Halim. 2005. Analisis Laporan Keuangan. Edisi Kedua, Cetakan Pertama. Yogyakarta : YKPN.

Munawir. 2002. Analisa Laporan Keuangan, Edisi Keempat. Yogyakarta: Liberty.

Ndaru Hesti Cahyaningrum. 2012. Analisis manfaat rasio keuangan dalam Memprediksi pertumbuhan laba (Studi Kasus: Perusahaan Manufaktur Yang Terdaftar Di Bursa Efek Indonesia regresi untuk debt to equity ratio bernilai positif $(0,021)$, berdasarkan hasil uji $t$ diperoleh koefisien regresi untuk working capital to total assets ratio bernilai negatif (1,586), berdasarkan hasil uji $t$ diperoleh koefisie regresi untuk total assets turn over ratio bernilai negatif $(-0,479$ Berdasarkan hasil uji t diperoleh koefisien regresi untuk net profit margin ratio bernilai positf $(2,023)$, rasio keuangan yang terdiri dari debt to equity ratio, working capital to total assets ratio, total assets turn over ratio dan net profit margin ratio secara bersama-sama berpengaruh sebesar 98,4\% dalam memprediksi pertumbuhan laba pada Distributor Prima Palopo. Sedangkan sisanya yaitu sebesar 1,6\% dipengaruhi oleh faktor lain yang tidak diteliti pada penelitian ini.

Periode 2005 sampai dengan 2010).Semarang: Universitas Diponegoro.

Parawiyati, Ambar Woro Hastuti dan Edi Subiyantoro. 2000. Penggunaan Informasi Keuangan untuk Memprediksi Keuntungan Investasi bagi Investor di Pasar modal, Jurnal Riset Akuntansi Indonesia Vol. 3 No. 2 : 214-228.

Riduwan dan Akdom. 2007.Rumus dan Data Dalam Analisis Statistik, cetakan kedua. Bandung: Alfabeta.

Sartono, Agus. 2001. Manajemen Keuangan Teori dan Aplikasi. Edisi Keempat. Cetakan Pertama. Yogyakarta: BPFE.

Syafri, Syofan, Harahap. 2004. Teori Akuntansi. Jakarta: PT.Raja Grafindo Persada.

Sofyan Safri Harahap. 2002. Teori Akuntansi Laporan Keuangan. Jakarta: Bumi Aksara.

Warsono. 2003. Manajemen Keuangan Perusahaan. Jilid Pertama. Edisi Ketiga. Penerbit: Bayumedia Publishing.

Zainuddin dan Jogiyanto Hartono. 1999. Manfaat Rasio Keuangan dalam Memprediksi pertumbuhan Laba : State Studi Empiris pada Perusahaan Perbankan yang terdaftar di Bursa Efek 
Jakarta, Jurnal Riset Akuntansi Indonesia Vol. 2 No. $1: 66-90$. 